\title{
Corporate Social Responsibility as a Tool to Face Climate Change
}

\author{
Alexis Santiago Pérez Figueredo \\ Center for Multidisciplinary Studies of Coastal Zones, University of Orient, Santiago de Cuba, Cuba \\ Email address: \\ alexis.figueredo@uo.edu.cu

\section{To cite this article:} \\ Alexis Santiago Pérez Figueredo. Corporate Social Responsibility as a Tool to Face Climate Change. Journal of Photonic Materials and \\ Technology. Vol. 6, No. 1, 2020, pp. 7-13. doi: 10.11648/j.jmpt.20200601.12
}

Received: July 24, 2020; Accepted: August 17, 2020; Published: September 16, 2020

\begin{abstract}
This work aims to analyze Corporate Social Responsibility as a methodological tool that, applied in the company's strategic management model, contributes to the development of capacities to face climate change stimulating the development of good practices demonstrating its environmental performance. The methodology used took into account comparative studies, the descriptive-explanatory method, the bibliographic and documentary review, as well as the causal analysis in the company-environment-society relationship in the framework of the impacts of climate change as well as the modeling used in the presentation of the procedure. As a result, a procedure is proposed that starting from the conception of the strategic projection of business management; elements of Corporate Social Responsibility are taken into account to contribute in Cuban companies to the implementation of the State Plan of the Republic of Cuba to confront change climate: Life Task. Promoting the development of actions that contribute to raising the perception of risk and the environmental performance of the institution evidenced through good practices.
\end{abstract}

Keywords: Corporate Social Responsibility, Business Management, Environmental Performance, Risk Perception, Climate Change

\section{Introduction}

In origins of Corporate Social Responsibility (CSR) most of the authors who have addressed the issue, Galindo, Maldonado, cited by Correa, et al and Aristimuño M, agree that its appearance occurs in the first decades of the 20th century. Due to the beginning of the First and then to the Second World War, an interruption in its development occurred until the end of the 1940s. [1-3]

At the beginning of the fifties of the last century its development was renewed influenced by the emerging awareness that was brewing about the environmental problem determined by the public interest in knowing the responsibility of different companies with the use and destination of some products, mainly chemicals used during World War II with warlike interest, but once the conflict ended, their use in agriculture and other purposes were more frequent as components of fertilizers, insecticides, cosmetic industries, among other uses that began to worry the society.

Starting in the 1960s the development of environmental thought influenced the increase in the recognition of corporate social responsibility, especially in the private sector, which increased with the emergence of different environmental groups, opening spaces for participation, and the development of consciousness the environment of society.

In the $70 \mathrm{~s}$ of the last century, the development of the concept of environmental management, elements on cleaner production and environmental ethics contributed to its conceptualization and development as a theoretical construction, which influenced its evolution and recognition at the end of these years. At the beginning of the $80 \mathrm{~s}$, the accumulated knowledge determines that it began to be considered as an element in business management aimed at developing actions that minimize the impact of the company's production internally and in the community that influence the improvement and projection of the company.

Precisely in these years the development and application of the concept of CSR spread throughout Europe, while in Latin America its treatment as Corporate Social Responsibility (CSR) is consolidated between the two, there are no substantive differences, beyond that in the corporate approach, 
responsibility It transcends from its organizational culture, showing the set of values, objectives, and commitments of a company that makes it different from others. [4-6]

With the conceptualization of the paradigm of Sustainable Development at the end of the eighties of the last century, which was later coined at the Rio Summit in 1992, the increase in environmental legislation, norms, and treaties, as well as business action policies have stimulated the formation of social organizations and interest groups, which promote and demand a more serious and coherent commitment in meeting the needs of society and in the search for solutions to the impacts generated by companies and industry on the environment.

The objective of this work is to demonstrate how CSR can be used as a methodological tool when applied in the business management model, contributes to the development of capacities to face climate change, promoting the development of good practices that demonstrate levels of perception of risk and environmental performance of the institution.

Materials and methods

The comparative and descriptive-explanatory method was used to analyze the different conceptions of CSR development at different stages and regions, as well as to support its evolution. The bibliographic and documentary review to establish the state of the art and the theoretical framework of this study. The causal analysis allowed to deepen the relationship between the company and the environment in the context of the impacts of climate change and the modeling was used in the presentation of the procedure.

For the development of this work, the following methodological scheme was taken into account:

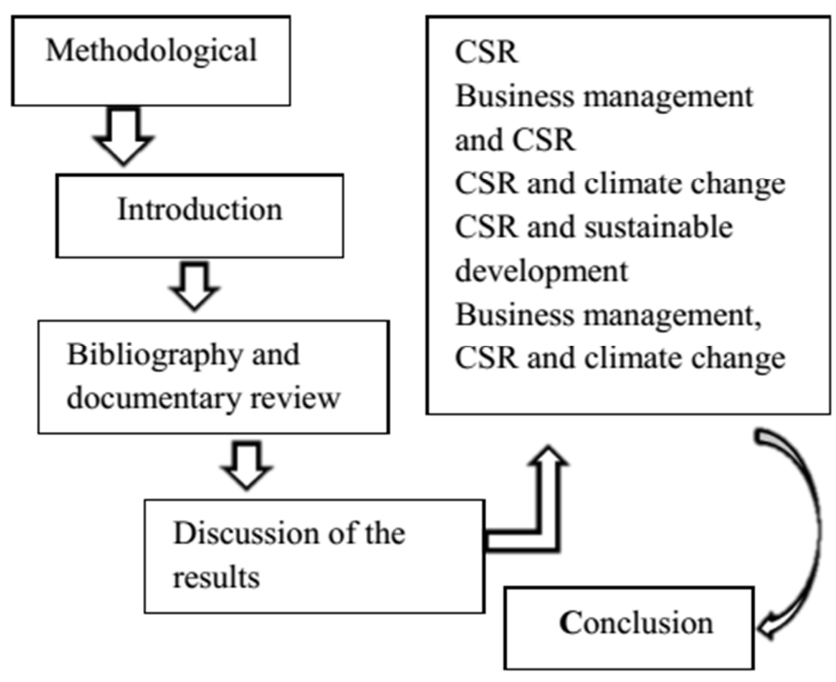

Figure 1. Methodological scheme.

\section{Results and Discussion}

\subsection{Corporate Social Responsibility}

In 1999 the holding of the World Economic Forum (WEF) in Davos, Switzerland recommended companies to adopt new principles in their management in relation to clarifying their position in the field of human rights, labor standards, and the environment. What constitutes in itself, a declaration for the company to assume Corporate Social Responsibility and its conscious, clear and sustained incorporation in the strategic management of the organization, recognizing the impacts of its activity on the environment.

The Confederation of Business Organizations of the Valencian Community cited by Gonzalez, et al, [7] considers that "the range of definitions moves, from the narrowest conception, which identifies CSR with the good fulfillment of the mission of the organization, to the most complete, that notion with a comprehensive operating strategy and business culture that is projected towards all its partners (customers, shareholders, workers, suppliers, investors or other groups of interested parties) harmoniously combining the objectives of the company or corporation with social and environmental concerns of the environment where it acts, voluntarily incorporating commitments that transcend the legally or conventionally established obligations.

For the International Labor Organization (ILO), cited by González and another [4-7], corporate social responsibility is the set of actions that they take into account so that the development of their activities has a positive impact on society and reaffirms the principles and values that govern, both with their own internal methods and processes and in their relationship with other development actors and the community.

According to the Guide for the implementation of ISO 26 000, [8] CSR is a means to achieve the benefits of operating in a socially responsible manner and to express its commitment to the well-being of society and the environment that has become a central criterion to measure your overall performance and your ability to continue to operate effectively.

From the analysis of these considerations, it can be established that a company that assumes CSR transcends the company's ethical commitments towards its workers, projecting itself to society and the environment, expressing its responsibilities, among others, to:

Serve society with useful products and in fair conditions,

Create wealth in the most efficient way possible by promoting the rational use of resources.

Respect the rights of workers with decent working conditions that favor their safety, occupational health and human and professional development,

Respect the environment, avoiding as much as possible any type of contamination, minimizing the generation of waste and rationalizing the use of natural and energy resources,

Integrate, implement, and promote socially responsible behavior throughout the organization and, through its policies and practices, within its sphere of influence in the community.

Contribute to tackling climate change and promote the assessment of environmental and social risks to improve solutions.

These commitments demonstrate that the main objective of the company that practices CSR is to promote social responsibility in all areas of society, with all citizens, public or 
private institutions, and social organizations, in general, to contribute to increasing the well-being of the society.

Some authors begin to use the terms organizational social responsibility (RSO), identifying the work of interest groups: companies, unions, universities, NGOs, political parties, public administrations, employers, the media, etc. As well as, the concept of Corporate Governments identified as the structure of government that is based on the distribution of rights and responsibilities among the different participants in society, such as the board, managers, shareholders and other economic agents that maintain some interest in the company. $[6,8,9]$

These evaluations show that this concept has different interpretations and uses, depending on who uses it. But in summary, they agree that it refers to a company that is socially responsible when, in its decision-making process, it evaluates the impact of its actions on communities, workers and the environment and effectively incorporates its interests in the search for solutions in their management processes and the scope of their results.

\subsection{Business Management and CSR}

The adoption of CSR by the company constitutes a change in the perception of how it interprets its relationship not only with the environment but with other development actors with whom it shares the responsibilities and commitments of development in the territory.

In the treatment of the subject, some authors such as Correa, J., Guerra, A., Jaramillo, J, et al and in the guide for the implementation of ISO 26000 [2, 8], affirm that although there is a criterion that it is a declaration of voluntary action, this should not be understood as a result of unplanned and organized activities, so its constitution must be conceived based on the company's strategic management model that assesses the impacts of its activity or business on the internal and external environment to achieve a balance of the social and environmental scope of its action as a complement to the traditional criteria to measure and evaluate the profitability and financial management of the organization.

Considering CSR in the strategic environment of the organization in fact establishes a synergy with the entity's own values and the ethical basis of CSR attributed to compliance with the regulations and laws that support its commitments to society, the environment, and other territorial development actors. [8]

The strategic environment of the organization guarantees that CSR is assumed by all members of the company, involving everyone regardless of the level or position they have in it, that it is expressed as part of the organizational culture, and constitutes one of its shared values.

Companies and their stakeholders are increasingly aware of the need and benefits of socially responsible behavior that has become an important criterion for the company because it affects its image, creates a competitive advantage, influences the development of beneficial relationships for the community, and with other local development actors.

The ethical behavior of the company favors its adherence to the observance of the regulatory and regulatory framework related to the fulfillment of its corporate purpose and the creation of goods and services that promote the welfare of society.

The companies and organizations that assume CSR can carry out various actions and have a range of possibilities that respond to the context and uniqueness of each company, which can identify those aspects that require greater attention, an example illustrated in the following table 1 .

Table 1. CSR relationship with its stakeholders.

\begin{tabular}{|c|c|c|}
\hline Interest Group & Practice & Actions \\
\hline \multirow[t]{2}{*}{ Human resources } & Preparation of Human Resources & Training, courses \\
\hline & Safety and health of workers & $\begin{array}{l}\text { Create an appropriate work environment, control, and compliance with protection and } \\
\text { hygiene standards, among other actions }\end{array}$ \\
\hline \multirow[t]{2}{*}{ Environment } & $\begin{array}{l}\text { Promote the control and rational use of } \\
\text { energy resources. }\end{array}$ & $\begin{array}{l}\text { Development of good practices and application of appropriate technologies that guarantee } \\
\text { the saving of these resources. }\end{array}$ \\
\hline & Promote recycling actions & Support raw material collection campaigns and recycling actions. \\
\hline \multirow[t]{2}{*}{ Community } & $\begin{array}{l}\text { Development of activities in } \\
\text { coordination with the community }\end{array}$ & $\begin{array}{l}\text { Increase in green areas, support in environmental sanitation campaigns, attention to health } \\
\text { centers and education. }\end{array}$ \\
\hline & $\begin{array}{l}\text { Control of dumping and final deposit of } \\
\text { remainders }\end{array}$ & $\begin{array}{l}\text { Promote the good practices directed to the reduction of pollutant loads and support to } \\
\text { campaigns of education in this sense. }\end{array}$ \\
\hline
\end{tabular}

Source: Adapted from Gonzalez, et al [6].

\subsection{CSR and Sustainable Development}

The social, environmental, and economic situation of the planet has generated concerns and expectations in society, companies, entities, and organizations that have become aware of the importance of seeking solutions to these current problems, taking into account the possibility of modifying or reversing this situation and guarantee future generations the resources and conditions necessary to satisfy their own needs. This approach forms the basis of the concept of sustainable development.
The achievement of future sustainability depends on the construction of a sustainability platform with actions that can be developed in the present, bearing knowledge based on an ethical definition that favors promoting the company's management levels in the search for solutions to the problems you are facing.

What requires the paradigm shift in strategic thinking, the concept of defining the objectives of the company to achieve the mission, towards the approach based on achieving the future vision of how it wants to be recognized, which positions 
the company in the strategic management paradigm.

Since the beginning of this century, it has been a constant concern of the international community to establish guidelines that contribute to the achievement of objectives related to meeting the needs and well-being of humanity. This is how in 2000 eight goals were established, known as the Millennium Goals (MDGs) that outline the roadmap to achieve until 2015.

The evaluation of compliance with the MDGs in that year determined that the weight of progress achieved, there were still dissatisfactions, but also demonstrated coordinated action was possible, so a new program of objectives was necessary for its achievement: the 2030 Agenda. [10,11]

The Sustainable Development Goals (SDGs) or 2030 Agenda are a set of 17 goals and 169 goals, aimed at solving the social, economic and environmental problems that affect the world, spanning the next 15 years (2015-2030).

Corporate Social Responsibility for its adherence to ethics is a valuable methodological tool to establish the company's commitments in relation to society and its environment, outside the financial and economic limits. Taking into account the conception of the objectives for the achievement of Sustainable Development, the 2030 Agenda, CSR can contribute to the fulfillment of the objectives and goals of this agenda, making the company a vehicle for the implementation and demonstration of its commitment to sustainable development.

A socially responsible organization, due to its projection, has a high evaluation in the achievement of the objectives of sustainable development, promoting synergies from the organization, planning, execution, control, and evaluation of actions to achieve these objectives.

For example,

The first SDG (End of Poverty) the contribution to an employment policy for the community and pay adequate and decent costs.

SDG Goal 3 Guaranteeing a healthy life and promoting the well-being of all is reflected in the will of the socially responsible company for adequate labor policy, decent employment, and concern for the health and social security of its workers and families.

We could also consider facilitating access to education and lifelong learning for members of the organization and contributing to the community at the facility to accomplish this effort for its members.

SDG 12 (Responsible Production and Consumption) When communicating with consumers, a responsible organization must provide complete, accurate, and understandable information about their productions, calling for their responsible consumption.

The SDGs can be a business-planning tool and their long-term vision will become a reference to define the scope of CSR commitments adjusted to these objectives.

The 2030 Agenda is a transformative and inclusive agenda, which places the equality and dignity of people at the center and calls for changing our style of development, respecting the environment, which is also CSR objectives.

\subsection{Business Management, CSR, and Climate Change}

The existence of planetary climate change (CC) is confirmed by a group of scientists who make up the Intergovernmental Group on Intergovernmental Climate Change (IPCC). The increase in meteorological events and other extreme events (heat waves, hurricanes, floods, droughts, forest fires, among others), constitute in one way or another a cause and effect relationship of $\mathrm{CC}$.

The causes of CC are generally natural in nature but, in the last 150 years, due to human activities since the beginning of the industrial age, they are mainly anthropic. The social causes of CC include the emission of greenhouse gases (GHGs), including carbon dioxide and methane due to the combustion of fossil fuels and agricultural activities, among other human activities. [12]

In the diversity of actors in the territory that contribute a greater pollutant load, companies constitute it and at the same time they can play an active role in the measures that can be taken to reduce or mitigate these loads, in response to the commitments they have assumed as an expression of their social responsibility towards the environment and society.

One of the tasks in which the role of companies is decisive is the training of capacities to face climate change, not only in their own human resources but also in the communities where they are located. [13]

They could generate an important contribution in the analysis that must be carried out to promote the change of appropriate and environmentally friendly technologies and the design of the strategies that must be adopted to reduce vulnerabilities, promoting the development of good business practices carrying a greater social resilience to face climate change

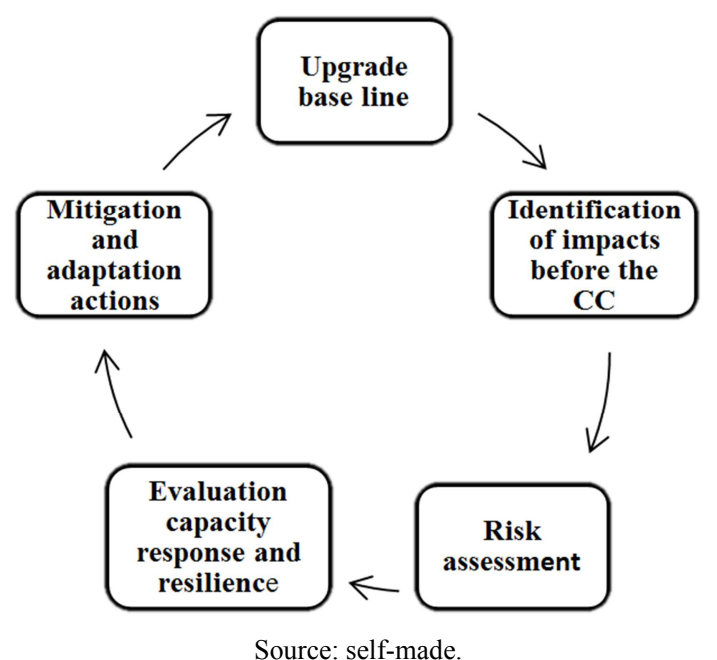

Figure 2. Profile of impacts of climate change.

The consequences of $\mathrm{CC}$ also have a social implication due to the impacts of hurricanes, floods, droughts, forest fires that cause population displacement, increased morbidity of different pathologies related to human health, for example, respiratory diseases, dermatological, among others, as well as the effects on the domestic economy, and the availability of 
drinking water.

This knowledge of how CC can influence the community must be recognized by companies in order to develop actions aimed at its prevention, mitigation, or adaptation. [14] But internally, the company must also know how it can be affected by $\mathrm{CC}$ in the different processes that the company carries out for it, they must know its profile on the impacts of climate change (Figure 2).

\section{Discussion of the Results}

Based on the principles of CSR, the objectives of the 2030 agenda, the budgets of the Cuban State Plan is to face climate change: Life Task and the management of the company established the fundamental elements of the procedure to incorporate CSR in the strategic management model of the company to face the impacts of climate change. [12]

For this, it is important, first of all, to build the profile of the impacts of the company's CC to achieve its recognition, evaluation, and characterization, minimizing the level of uncertainty associated with them.

This action allows established the values of environmental quality and enhancing the perception of risk that exists in the community and defining strategies to improve capacities to face climate change with approaches to mitigation or adaptation materialized with the development of good practices that carry the resilience achieved and demonstrative of the environmental performance achieved.

The following diagram shows the model for this procedure. (Figure 3)

\section{CORPORATE SOCIAL RESPONSIBILITY AS A TOOL FACE CLIMATE CHANGE}

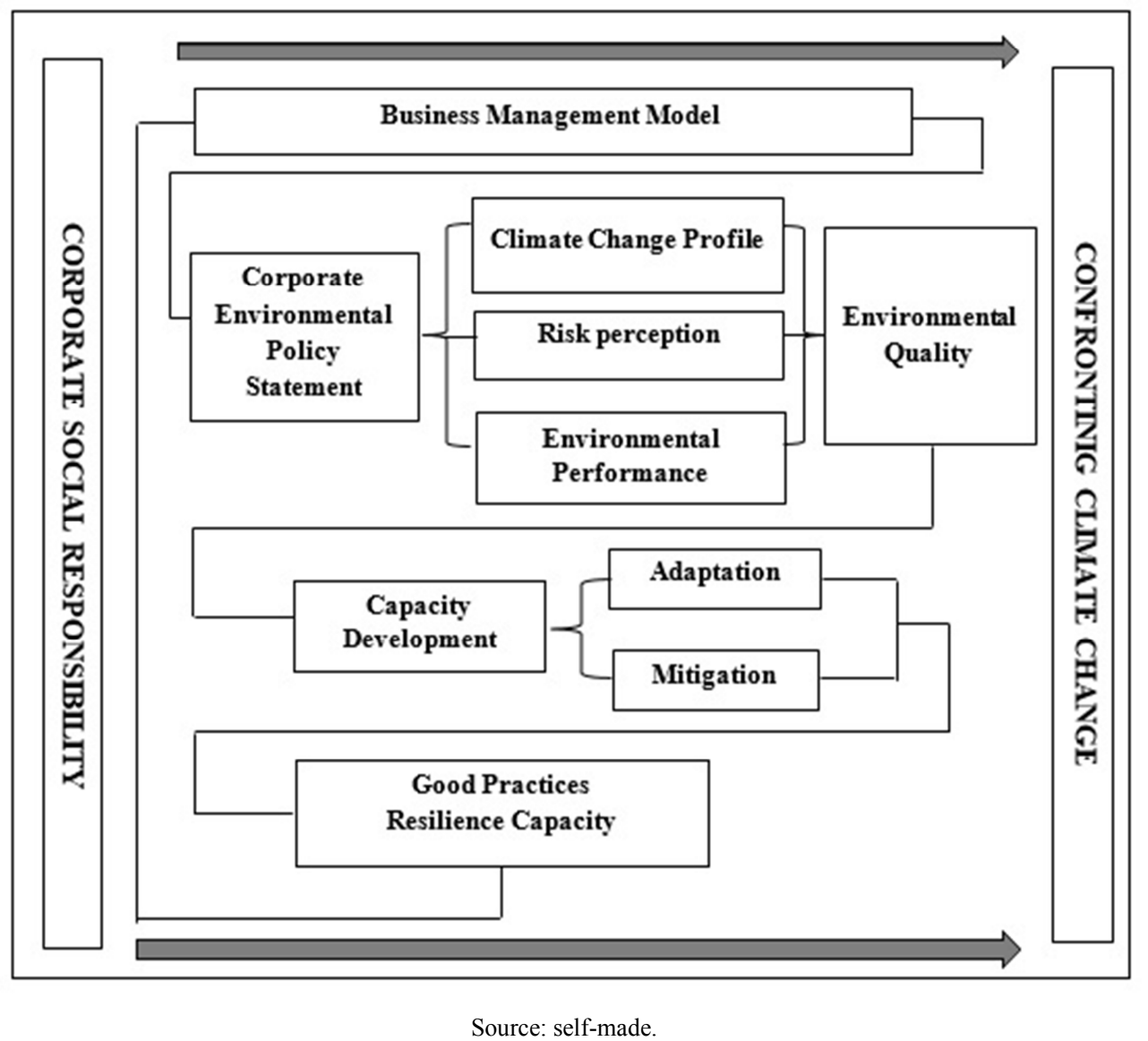

Figure 3. Model of the procedure.

It is important to take into account as a starting point, the foundations of CSR that guarantee that the work corresponds to these principles aimed at achieving:

Transparency and consistent action evidenced through accountability.

Ethical behavior in relation to the fulfillment of its commitments.

Respect for the interests of stakeholders.

Respect for the legal and regulatory framework.

Respect for the environment.
Respect for human rights.

To have as reference the task ten of the State Plan of the Republic of Cuba to face climate change: Life Task, in even though in all the tasks that this plan conceives the CSR has a transversal incidence. In this task number ten, makes it possible to influence in a vital area such as the training of human resources and their preparation to face $\mathrm{CC}$ as a process of capacity building and enhancing risk perception. [12, 15]

In relation, it is evidenced through the following table 2. 
Table 2. Projection of CSR relationships with the elements of business management, the 2030 Agenda, and the Life task.

\begin{tabular}{|c|c|c|c|c|}
\hline $\begin{array}{l}\text { Management } \\
\text { process business }\end{array}$ & CSR elements & Agenda 2030 & Life Task Task 10 & Actions to develop \\
\hline HR Management & $\begin{array}{l}\text { Ethics } \\
\text { Respect for MA } \\
\text { Respect for human rights } \\
\text { Compliance with the legal } \\
\text { and regulatory framework }\end{array}$ & $\begin{array}{l}\text { Cross-cutting axis } \\
\text { The SDGs are a business planning tool that } \\
\text { your long-term vision becomes a reference } \\
\text { to define the scope of CSR commitments } \\
\text { adjusted to these objectives }\end{array}$ & $\begin{array}{l}\text { Enhance risk } \\
\text { perception in the } \\
\text { face of climate } \\
\text { change }\end{array}$ & $\begin{array}{l}\text { Rational use of resources } \\
\text { Pollution reduction } \\
\text { Protection of workers and } \\
\text { the community }\end{array}$ \\
\hline
\end{tabular}

Source: self-made.

According to specialist studies, there are insufficiencies and gaps in training and knowledge on risk management in tackling climate change, which influences risk perception and the preparation of decision-makers and development actors in the territories and conditions the problem situation that determines this issue. Which is analyzed in Table 3, so it is necessary to establish actions that allow development towards a process of change that allows:

Strengthen the ties between the institutional, social, and economic dimensions for risk management.

Know the impacts of climate change that they must face.
Manage vulnerabilities associated with climate change effectively.

Create synergies between measures and actions, as well as overcome possible improvisation costs.

Optimize the allocation of available resources against climate change and adaptation.

Promote collaboration between the public and private sectors in adaptation.

Create a common prevention culture in terms of adaptation to climate change $(\mathrm{CC})$.

Table 3. Analysis of the causes and effects of the problem situation studied.

\begin{tabular}{|c|c|c|c|c|}
\hline Effects & Problems & Cause, limited training actions & $\begin{array}{l}\text { Cause, Weak communication } \\
\text { strategy }\end{array}$ & $\begin{array}{l}\text { Limited } \\
\text { Infrastructure Cause }\end{array}$ \\
\hline $\begin{array}{l}\text { Low-risk } \\
\text { perception } \\
\text { due to the } \\
\text { impacts } \\
\text { generated by } \\
\text { the CC }\end{array}$ & $\begin{array}{l}\text { Limited knowledge of risk } \\
\text { management in the face of } \\
\text { the impacts generated by } \\
\text { the } \mathrm{CC} \text { in the territory that } \\
\text { conditions its preparation } \\
\text { and development of } \\
\text { response capacities. }\end{array}$ & $\begin{array}{l}\text { Insufficient knowledge of risk management in } \\
\text { decision-makers and development actors. } \\
\text { 1. a) Gaps in the curricula on risk management } \\
\text { issues } \\
\text { 2. The short course offers of training courses on } \\
\text { risk management for CC. } \\
\text { 2. a) Obsolete diagnosis of learning needs on } \\
\text { this subject in companies and institutions }\end{array}$ & $\begin{array}{l}\text { 1. a) Insufficient public good } \\
\text { strategies on the subject in } \\
\text { entities and governments. } \\
\text { 2) Prevalence of a reactive } \\
\text { approach to managing } \\
\text { information and communication } \\
\text { on risk management }\end{array}$ & $\begin{array}{l}\text { Poor infrastructure for } \\
\text { risk management } \\
\text { 1. a) Few financing } \\
\text { projects }\end{array}$ \\
\hline
\end{tabular}

Source: self-made.

As part of Cuban environmental policy, the State Plan for tackling climate change is being developed in the country: Life Task.

The implementation and adaptation of this plan is mandatory for all Organisms of the Central State Administration (OACE). So it is necessary to provide a way of doing it at the level of companies or territories, explaining about this serious event and its consequences, both for the economy of the country as well as for society and the environment that allows decision-makers to develop actions aimed fundamentally at creating capacities to cope with the impacts of climate change. $[12,15]$

This plan must conceptualize integrated actions that contain the steps that must be taken in an orderly manner, determine the priorities and actions that must be carried out considering the profile of climate change impacts and the uniqueness of the locality, to identify the dangers associated with $\mathrm{CC}$. The assessment of vulnerabilities and response capacity to project actions from the mitigation or adaptation perspective considering short, medium, long, and very long-term scenarios.

Table 4. Below provides criteria on how to organize actions to complete task ten.

\begin{tabular}{|c|c|c|c|c|}
\hline Task 10 & verall objective & wareness moment & Training moment & oment \\
\hline $\begin{array}{l}\text { Prioritize measures and } \\
\text { actions to increase risk } \\
\text { perception and increase the } \\
\text { level of knowledge and } \\
\text { degree of participation of } \\
\text { the entire population in } \\
\text { facing the impacts of } \\
\text { climate change and a culture } \\
\text { that encourages water } \\
\text { saving }\end{array}$ & $\begin{array}{l}\text { Develop actions for capacity } \\
\text { building in actors and } \\
\text { decision-makers, promoting } \\
\text { the perception of risk in the } \\
\text { process of coping with the } \\
\text { impacts associated with } \\
\text { climate change in the } \\
\text { territory, contributing to a } \\
\text { culture of rational use of } \\
\text { water resources. }\end{array}$ & $\begin{array}{l}\text { Provide environmental } \\
\text { training courses on risk } \\
\text { management in the face } \\
\text { of climate change taking } \\
\text { into account the } \\
\text { characteristics of the } \\
\text { study unit } \\
\text { Characterize the impacts } \\
\text { of climate change on the } \\
\text { company. }\end{array}$ & $\begin{array}{l}\text { Develop participatory } \\
\text { workshops for the identification } \\
\text { and evaluation of the impacts of } \\
\text { climate change, evaluating the } \\
\text { response capacity present in the } \\
\text { study unit. } \\
\text { Risk assessment and its } \\
\text { stratification. } \\
\text { Develop the construction of CC } \\
\text { impact profiles. }\end{array}$ & $\begin{array}{l}\text { Development of adaptation } \\
\text { actions or to minimize the } \\
\text { identified impacts of CC. } \\
\text { Development of good } \\
\text { practices for risk reduction } \\
\text { management before the CC }\end{array}$ \\
\hline
\end{tabular}




\begin{tabular}{lll}
\hline Generalization moment & Evaluation and improvement moment & Verifiable transformation indicators \\
\hline & Verifiable output indicators & In the courses and workshops developed in each of the \\
& 1. At least 2 workshops are held in each selected study unit & selected study units, X people from the companies of the \\
2. At least 2 courses are taught for each selected unit of study. & territory are trained. \\
3. The impact profiles on climate change of the study units are & At least one social communication campaign is \\
constructed. & 4. Action plans are designed to minimize the identified impacts of & communication are used so that more than 70 percent of \\
CC or improve adaptability to them. & the population recognizes the main impacts of climate & change and how they can be faced. \\
\hline
\end{tabular}

\section{Conclusion}

Organizations around the world, and their stakeholders, are increasingly aware of the need and benefits of socially responsible behavior towards the environment, society, and the company within them, becoming a central criterion for Measure your overall performance and your ability to continue operating effectively. The objective of corporate social responsibility is to contribute to achieving sustainable development.

Climate change constitutes an irrefutable reality aggravated by human action in recent years, which has generated environmental problems that have gradually become a determining factor in achieving the sustainable development of the country.

The scenarios that scientists have predicted for the short, medium and long term on the magnitude and manifestation of their impacts demand immediate responses from society, so that, as far as possible, mitigate their impacts or develop adaptation actions to them.

Companies can constitute among the actors in a territory the entities that pollute the most, but at the same time, they constitute one of the most solid pillars to minimize these polluting loads.

The CSR constitutes, by its ethical foundations and principles, a valuable methodological tool to achieve the implementation and development of the State Plan of the Republic of Cuba to confront Climate Change; Life Tasks.

\section{Acknowledgements}

To colleagues at the Center for the Study of Coastal Zones at Universidad de Oriente for their help and collaboration in the discussion of this article.

To Deneysi Pérez and Maricela Alvarez for her valuable contribution to the translation and correction of the article in English.

\section{References}

[1] Aristimuño, M. (2010). La Responsabilidad Social Empresarial (RSE), como valor organizacional en la Pequeña y Mediana Industria en Eighth LACCEI Latin American and Caribbean Conference for Engineering and Technology "Innovation and Development for the Americas", June 1-4, 2010, Arequipa, Perú.pdf.

[2] Correa, J., Guerra, A., Jaramillo, J, et al. (2007). Evolución Histórica de los conceptos de RSE y balance social. Revista
Semestre $\quad$ Económico, $10 \quad$ (20), 87-102. https://repository.udem.edu.co/bitstream/handle/11407/975/.pdf.

[3] Real Academia Española (RAE). (Diciembre de 2017). Recuperado el 3/3/2020 lengua española: http://dle.rae.es/?id=G09HIAP.

[4] Ministerio de Empleo y Seguridad Social de España. (2016) Estrategia Española de Responsabilidad Social de las Empresas. Gobierno de España.

[5] Asociación Española de Contabilidad y Administración de empresas. (2004.) Marco Conceptual de la Responsabilidad Social Corporativa. España: Documentos AECA, A. Serie Responsabilidad Social Corporativa, $\mathrm{N}^{\circ}$ 1. Recuperated $3 / 3 / 2020$.

[6] González, O, Molina, R., Patarroyo, D., et al. (2019). Estudio comparativo de las prácticas de Responsabilidad Social y Gobierno Corporativo en las Medianas Empresas de los valles de Tundama y Sugamuxi en Boyacá- Colombia Revista Espacios, Vol. 40, nº 14, 2019. Pág., 17.

[7] Confederación de organizaciones Empresariales de la Comunidad Valenciana (2016). Responsabilidad Social. Empresarial para Pymes. CIERVAL, 3.

[8] Norma ISO 26 OOO. Guía sobre Responsabilidad social empresarial. Repositorio Norma ISO. en www.iso.org. Recuperated 3/3/2020.

[9] González, P. (2017) El gobierno corporativo en el Brasil y el papel social de las empresas. Estudios Gerenciales, 2002, (83) p. 71-89. Disponible en Internet: http://www.redalyc.org/articulo.oa?id=21208304. Recuperated $3 / 3 / 2020$.

[10] Cepal. (2018). La Agenda 2030, un reto para América Latina. Documentos de la Cepal, septiembre 2018, Santiago de Chile.pdf.

[11] CepaL (2019). Repositorio. Cepal. La ISO 26000 y los ODS. Recuperado 3/3/ $2020 \mathrm{de} \mathrm{http//repositorio} \mathrm{Cepal.org.}$

[12] Citma. (2017). Folleto Enfrentamiento al Cambio Climático en la República de Cuba Tarea Vida, editorial Academia, Ciudad Habana.

[13] López, I. (2014). El cambio climático, ¿Reto para la Responsabilidad Social Empresarial, Revista Internacional de Organizaciones, nº 13, 2014, pág., 39-53.

[14] Toms, S. (2014). «Economic development, climate change and the limitations of corporate social responsibility». En Kathryn Haynes, Alan Murray, Jesse Dillard (eds.), corporate Social Responsibility, A Research Handbook, Abingdon: Routledge. Recuperated $3 / 3 / 2020$.

[15] ODS 2030. (2019) Informe Voluntario de Cuba cumplimiento de la Agenda 2030 sobre los ODS. La Habana Cuba. 